\title{
Odour compounds of the diatom Cocconeis scutellum: effects on benthic herbivores living on Posidonia oceanica
}

\author{
Friedrich Jüttner ${ }^{1}$, Patrizia Messina ${ }^{2}$, Carmela Patalano ${ }^{2}$, Valerio Zupo ${ }^{2, *}$ \\ ${ }^{1}$ Institute of Plant Biology, Limnology, University of Zürich, Seestrasse 187, 8802 Kilchberg, Switzerland \\ ${ }^{2}$ Stazione Zoologica Anton Dohrn, Functional and Evolutionary Ecology Laboratory, Punta San Pietro, 80077 Ischia, Italy
}

\begin{abstract}
Polyunsaturated aldehydes released by marine planktonic diatoms upon wounding have been extensively studied since the discovery that they reduce the hatching success of copepods. Diatoms are also abundant in benthic marine ecosystems. For this reason we investigated the presence and the possible ecological roles of Cocconeis scutellum parva, a diatom found tightly attached to the leaves of Posidonia oceanica. This diatom was previously demonstrated to play an important trophic role for the shrimp Hippolyte inermis, by influencing its sex reversal. In the present study, C. scutellum parva was isolated and cultivated and the volatile compounds released upon cell disintegration were identified by mass-spectrometric methods. We demonstrated the presence of unsaturated aldehydes with chain lengths from $C_{5}$ to $C_{10}$. Unexpectedly, we found $C_{6}$ compounds represented by 3(Z)-hexenal, 2(E)-hexenal, hexanal and hexanol-1 that resemble the typical bouquet observed in higher plants. Compounds not described before for diatoms were, among others, pentane-2,3-dione and octane-2,3-dione. Food choice experiments performed on 17 animal species associated with $P$. oceanica meadows indicated that these grazers recognise the presence of the odour compounds, exhibiting complex patterns of reactions according to their life strategies. The mosaic of results obtained at various concentrations, in different species, indicated that wound-activated infochemicals generate a web of communication among diatoms and benthic invertebrates.
\end{abstract}

KEY WORDS: Infochemical $\cdot$ Odour $\cdot$ Seagrass $\cdot$ Behaviour $\cdot$ Feeding $\cdot$ Wounding $\cdot$ Diatom

\section{INTRODUCTION}

Posidonia oceanica (L.) Delile is a Mediterranean seagrass characterised by high stability of associated plant and animal populations, long persistence and great ecological importance (Buia et al. 1992), since its extensive and dense coastal meadows are considered to be biodiversity hotspots (Orth et al. 2006). A complex web of trophic, physiological, spatial and chemical relationships is produced by the stable coexistence of associated plant (Michael et al. 2008) and animal (Buia et al. 2000) populations. The relationships between Hippolyte inermis Leach and its diatom food are an excellent example. $H$. inermis is a shrimp that lives in the leaf stratum of $P$. oceanica, whose periphyton is often diatom-dominated (De Stefano et al. 2000). $H$. inermis is considered an opportunistic herbivore, grazing on algae present on the leaves of P. oceanica and, therefore, ingesting large amounts of epiphytic diatoms (Zupo 2001). We demonstrated that the ingestion of diatoms ascribed to the genus Cocconeis (in particular C. neothumensis, C. scutellum parva and C. scutellum scutellum) triggers the apoptosis of its androgenic gland (Zupo \& Messina 2007), followed by the complete destruction of the male gonad and a shift to the female sex (Zupo 2000). This effect was demonstrated to be positive for natural populations since the production of young females in spring (when the abundance of Cocconeis spp. diatoms on the leaf stratum is very high) assures higher reproductive bursts (Zupo 1994). Therefore, in $H$. inermis, the ingestion of diatoms is helpful for natural populations and the pro-apoptotic 
compound (whose structure has not yet been identified; Nappo et al. 2009) present in these diatoms acts as a spring signal for the production of young females, probably due to a long co-evolutionary process (Zupo et al. 2007).

In other cases, secondary metabolites produce deleterious effects on consumers. Compounds responsible for the biological effects have been demonstrated to be volatile organic compounds (VOC) not present in intact cells but released by a lipoxygenase cascade upon cell wounding (Pohnert 2000, Jüttner 2005). Unsaturated aldehydes of the lipoxygenase cascade in planktonic diatoms exhibit teratogenic effects on copepod larvae and reduce the viability of their eggs (Miralto et al. 1999). Wound-activated diatom cells also release unsaturated aldehydes (Pohnert 2002) that are inhibitors of mitotic proliferation in sea urchin embryos (Miralto et al. 1999). Similar relationships, although less striking, were demonstrated between the crustacean Daphnia pulicaria and some freshwater diatoms (Carotenuto et al. 2005).

Secondary metabolites produced by the lipoxygenase pathway may also act as repellents against grazers (Fink et al. 2006). The lipoxygenase product 2(E), $4(E), 7(Z)$-decatrienal has been shown to act as a repellent for freshwater crustacean grazers (Jüttner 2005). Therefore, it is evident that diatoms producing volatile compounds have a range of possible consequences. Co-evolutionary processes may modulate their effects, as is the case of VOCs that have been shown to play a role in locating suitable habitats for aquatic insects (Evans 1982) and nematodes (Höckelmann \& Jüttner 2004). All this evidence indicates the presence of a complex network of relationships shaped by diatom infochemicals. The data published in recent years on this topic have spurred interest and several studies indicate benthic invertebrates can detect and differentiate VOCs released from diatoms (Jüttner \& Dürst 1997, Jüttner 2005) and utilise them as food-finding cues. In these cases, the diatom-produced infochemicals can be classified as foraging kairomones (Ruther et al. 2002).

Based on these assumptions, we may also ask if Cocconeis spp. diatoms, which are present in (and seasonally dominate; De Stefano et al. 2000) the leaf stratum of Posidonia oceanica with known effects on the physiology of selected shrimps (Zupo 2000), produce VOCs and if their 'odours' may act as food-finding cues for some of the typical animals associated with the leaf stratum of the seagrass. In fact, $P$. oceanica represents a nest environment for several invertebrates and some fish, especially in spring, which is also the season of maximum abundance of Cocconeis spp. in the leaf stratum (Mazzella \& Buia 1989, De Stefano et al. 2000). To answer this question, we analysed the VOC compo- sition of C. scutellum parva cultured in the laboratory, re-constructed its VOC bouquet from pure compounds and performed binary-choice experiments to test its effect on selected invertebrates and on juveniles of one fish species.

\section{MATERIALS AND METHODS}

Collection and culturing of epiphytic diatoms. Collecting and culturing Cocconeis scutellum parva is complex, since this diatom is very adhesive, slowgrowing and delicate. Therefore, the classical collection and selection methods (Chepurnov et al. 2004) used for other species of benthic or planktonic diatoms are not applicable. For isolation of Cocconeis spp., metal panels $(30 \mathrm{~cm} \times 40 \mathrm{~cm})$ were coated with a low adhesion silicon polymer (Terlizzi et al. 2000) and deployed in the harbour of Ischia (Gulf of Naples) at $2 \mathrm{~m}$ depth in April 2001. After 1 mo of exposure, panels were gently sprayed with seawater to remove foulers. Most Cocconeis spp. diatoms, being the most adherent epiphytes, were conserved on the surface. Several small samples of diatoms were obtained by scraping about $1 \mathrm{~cm}^{2}$ of the surface with the aid of a coverslip. The collected samples were individually suspended in Petri dishes containing $3 \mathrm{ml}$ of sterilised seawater. Cocconeis spp. diatoms were identified at the genus level by inverse optical microscopy, collected by means of a glass capillary tube connected to a micromanipulator (Leica Micromanipulator $\mathrm{M}$ ) and individually transferred to multiwell dishes (Falcon ${ }^{\mathrm{TM}}$ 35-3046, 6 wells of $5 \mathrm{ml}$ ) containing sterilised seawater. This operation was repeated several times, in order to separate the diatoms from bacteria, spores, cyanobacteria and other organisms (see Zupo \& Messina 2007 for details). The wells were examined every $3 \mathrm{~d}$ in order to monitor the growth of Cocconeis spp. When small clusters of diatoms were obtained, newly produced diatoms were transferred again, using a glass capillary tube connected to the micromanipulator, and cultured in sterilised f/2 Guillard's medium (Sigma G9903). We considered the diatom culture sufficiently clean after 3 transfers to new wells, and proceeded to species identification using scanning electron microscopy. Diatoms were subsequently scraped off using a sterilised Pasteur pipette, washed in distilled water and collected on a Millipore filter. The filter was then glued onto a microscopy stub and gold-sputtered prior to the observation. We were thus able to isolate 32 strains representing 5 species of epiphytic diatoms (C. neothumensis, C. scutellum scutellum, C. scutellum parva, C. posidoniae and Diploneis sp.). All these diatoms were conserved at the Benthic Ecology Laboratory of the Stazione Zoologica Anton Dohrn (Naples, Italy) in 
thermostatic chambers until used in experiments conducted in July 2008. Replicate cultures of each strain were maintained in different chambers, in $\mathrm{f} / 2$ medium at $18^{\circ} \mathrm{C}$, under a $12: 12 \mathrm{~h}$ photoperiod and irradiance of about $150 \mu \mathrm{mol} \mathrm{m} \mathrm{m}^{-2} \mathrm{~s}^{-1}$. Diatoms were transferred to new Petri dishes every $15 \mathrm{~d}$ and inspected monthly by inverse optical microscopy.

Preparation of diatoms for extractions. Six Petri dishes containing pure cultures of Cocconeis scutellum parva were completely scraped off using a sterilised Pasteur pipette and their content was pooled in a glass vessel. This suspension was used to prepare several cultures in $7 \mathrm{~cm}$ Petri dishes containing f/2 medium. When diatoms covered the bottom of the Petri dishes, they were collected, and the suspension obtained was used to inoculate 20 large (14 $\mathrm{cm}$ diameter) plastic Petri dishes containing f/2 medium. The large Petri dishes were then cultivated in a thermostatic chamber for a further $15 \mathrm{~d}$. The growth medium of each Petri dish was then removed and the dishes were frozen at $-20^{\circ} \mathrm{C}$.

Counts and cell volumes. The cells on the bottom of each Petri dish were counted under the inverse optical microscope. For this purpose, 20 fields were randomly chosen and examined; the diatoms present in each field were counted; finally, a proportion of the whole area of the plate was applied to calculate the average number of cells per plate. In addition, the average cell volume was calculated based on observations made on a single plate. For this purpose, 50 randomly chosen diatoms present on the plate were measured (length and width). The thickness of diatoms was impossible to evaluate in this way, since Cocconeis spp. cells are very thin and normally attached to the bottom. Therefore, 50 diatoms from the same strain were measured under the scanning electron microscope and an average thickness of $2.31 \mu \mathrm{m}$ was obtained. This thickness was then used for the calculation of the cell volume based on the formula (Hillebrand et al. 1999, Sun \& Liu 2003):

$$
\text { Volume }=\pi / 4 \times \text { length } \times \text { width } \times \text { thickness }
$$

Activation of Cocconeis scutellum parva. Petri dishes (14 cm diameter) with a dense layer of C. scutellum parva patches were kept frozen at $-20^{\circ} \mathrm{C}$. Analyses were carried out within $8 \mathrm{~d}$ after freezing. A Petri dish was taken out of the freezer and $5 \mathrm{ml}$ of brine ( $20 \% \mathrm{NaCl}$ in water, purified twice by stripping) was poured over the cell lawn. The cells of C. scutellum parva were physiologically disintegrated leading to the activation of lipoxygenase cascades and the formation of volatile compounds (Jüttner 2005). This was also indicated by the appearance of a strong rancid odour. The cells were detached with a rubber spatula and the suspension transferred into a round bottom flask of glass for stripping analysis. The time needed for this procedure was about $10 \mathrm{~min}$ and was sufficient to allow the production of VOCs.

Stripping analysis. The VOCs were concentrated by closed-loop stripping and analysed using gas chromatography-electron impact mass spectrometry (GCEIMS) (Durrer et al. 1999), but the Erlenmayer flask was replaced by a $250 \mathrm{ml}$ round-bottom flask. Brine was used to detach the cells on the Petri dish and to quantitatively transfer the suspension into the glass vessel. The stripping time was $45 \mathrm{~min}$ at $22^{\circ} \mathrm{C}$, after which most of the VOCs were adsorbed on Tenax TA. The Tenax-filled cartridge was removed, and the VOCs were thermally desorbed and transferred into a GC-EIMS as previously described (Jüttner 2005).

Identification of compounds. For identification of the VOCs, chromatograms of reference compounds that exhibited similar concentration as the cellular compounds were established. When the retention times and mass fragmentation patterns were identical for both the reference and the Cocconeis scutellum parva constituent, a compound was considered identified. Mass spectrometry (MS) data from the literature, the National Institute of Standards and Technology (NIST) library and our own library were used for preliminary identification.

Reference compounds. If not otherwise stated, the reference compounds were purchased from Fluka. 2(E),6(Z)-Nonadienal was from Roth. Unsaturated aldehydes, ketones (3,5-octadien-2-one) and alcohols (3,5-octadien-1-ol) of the $\mathrm{C}_{8}$ skeleton were obtained from fruiting bodies of commercial Agaricus bisporus (Tressl et al. 1982). Part of the brown mushroom cap was ground in an agate mortar, transferred with $50 \mathrm{ml}$ of water into a round-bottom flask and treated as above (see 'Stripping analysis') for stripping and gas chromatography-mass spectrometry (GC-EIMS) analysis. 1-Hexen-3-one was prepared from $10 \mu \mathrm{l}$ 1-hexen3-ol in toluene by oxidation with $\mathrm{MnO}_{2}\left(2 \mathrm{~h}\right.$ at $\left.50^{\circ} \mathrm{C}\right)$. $2(E), 4(E), 7(Z)$-Decatrienal was a synthetic compound (Wendel \& Jüttner 1996). Octane-2,3-dione was donated by Givaudan Schweiz.

Quantitative determination. Cocconeis scutellum parva was grown in Petri dishes because solid substrate was an essential prerequisite for cell growth. After decanting the medium, the wet biomass that was still attached to the Petri dish was frozen. The concentration per cell was calculated using an independent determination of the VOC of 1 and of 4 Petri dishes. Thawing and the addition of $20 \% \mathrm{NaCl}$ solution activated several lipoxygenase reaction cascades, and several volatile compounds were released. These odour compounds were concentrated by closed-loop stripping and analysed by GC-EIMS. The VOCs were determined using the integrated areas of single ions that were 
extracted from the total ion chromatograms. The following features were taken into account in the selection of ions: sufficient intensity, specificity for a particular compound and low contamination by other unresolved compounds. When the peak was contaminated by another compound, the uncontaminated half of the peak area was determined and doubled assuming peak symmetry. The calibration (3 replicates) was done with reference compounds under the same conditions as the samples. When reference compounds were not available in sufficient purity to allow calibration, total ion currents (in the ranges $\mathrm{m} / \mathrm{z} 33$ to $\mathrm{m} / \mathrm{z} \mathrm{M}+1$ ) were used, and calibration was performed with structurally related compounds. 2(E)-Hexenal was used to calculate 3(Z)-hexenal and 1-hexen-3-one, 1-octen-3-ol to calculate 2,5-octadien-1-ol, and 2(E)-octenal to calculate 3,5-octadien-2-one and 2(E)-nonenal.

Odour choice experiments. The experimental design consisted of 6 replicates of 5 individuals each, for 17 animal species associated with Posidonia oceanica meadows (Table 1). The specimens necessary for the experiment were collected in Lacco Ameno d'Ischia (Gulf of Naples) by a circular net $(1 \mathrm{~m}$ diameter; $300 \mu \mathrm{m}$ mesh), trawled on the surface of $P$. oceanica leaves, at a depth between 5 and $12 \mathrm{~m}$. After collection, the fauna was sorted into 17 species (considering only those for which at least 40 individuals were available) and maintained in aerated and filtered seawater for $24 \mathrm{~h}$ up to the start of the experiment.

Odour choice tests were conducted (Wiesemeier et al. 2007) in order to distinguish positive and negative chemotaxis, mediated through the VOCs of Cocconeis scutellum parva. They may demonstrate odour preferences resulting from taste-receptor-mediated effects

Table 1. Species sampled in a Posidonia oceanica meadow in the Gulf of Naples, Italy, and considered in the experiment

\begin{tabular}{|llll|}
\hline No. & Species & Taxon & Feeding habit \\
\hline 1 & Hippolyte varians & Decapod crustacean & Opportunistic herbivore \\
2 & Hippolyte inermis & Decapod crustacean & Opportunistic herbivore \\
3 & Alvania lineata & Gastropod mollusc & Epiphyte grazer \\
4 & Rissoa variabilis & Gastropod mollusc & Epiphyte grazer \\
5 & R. violacea & Gastropod mollusc & Epiphyte grazer \\
6 & R. auriscalpium & Gastropod mollusc & Epiphyte grazer \\
7 & Pusillina sp. & Gastropod mollusc & Epiphyte grazer \\
8 & Gibbula umbilicaris & Gastropod mollusc & Epiphyte grazer \\
9 & Cestopagurus timidus & Decapod crustacean & Omnivore-detritivore \\
10 & Gammarella fucicola & Amphipod & Detritivore-herbivore \\
11 & Bittium reticulatum & Gastropod mollusc & Herbivore-detritivore \\
12 & Dynamene cf. bifida & Isopod & Scavenger-herbivore \\
13 & Halacarus sp. & Arthropod & Herbivore-detritivore \\
14 & Thoralus cranchii & Decapod crustacean & Opportunistic detritivore \\
15 & Syllis prolifera & Polychaete & Detritivore-herbivore \\
16 & Platynereis sp. & Polychaete & Herbivore \\
17 & Symphodus ocellatus & Fish & Omnivore \\
\hline
\end{tabular}

on odour patch residence time. The odour choice assays were performed in Petri dishes (diameter $14 \mathrm{~cm}$, height $2 \mathrm{~cm}$, total volume $307 \mathrm{ml}$ ) in a room at $22^{\circ} \mathrm{C}$. Each Petri dish was filled with $200 \mathrm{ml}$ of filtered seawater (Sanders $^{\mathrm{TM}}$ Protein Skimmer, Eheim ${ }^{\mathrm{TM}}$ mechanicaladsorbent filter, and UV steriliser) and placed on a paper sheath printed with 2 experimental arenas (Fig. 1a). Each arena (diameter $14 \mathrm{~cm}$ ) contained: 2 rectangles at the 2 opposite ends of a diameter, 1 reserved for the sample, the second for the control; a central circle, used for the first deployment of 5 individuals of each species; and 4 vertical lines, delimiting 5 zones. The central zone was ranked zero, and it was the largest, to host most ambiguous individuals and avoid erroneous assignments. The 2 zones near the sample $(+)$ were ranked 1 and 2 , respectively. The 2 zones near the control (-) were ranked -1 and -2 , respectively (Fig. 1a). The positions of the $2(+)$ targets, in the 2 arenas in each sheath, were opposed. Thus, external factors that might influence the movement of animals (e.g. light, magnetism, etc.) were kept random between the replicates, thereby excluding directional effects introduced by the experimental setup.

The agarose gel was prepared before the odour choice assays. We dissolved $1.2 \mathrm{~g}$ of low-melt agarose (Sigma A 9045) in $200 \mathrm{ml}$ of filtered and sterilised seawater at $80^{\circ} \mathrm{C}$ and added $3.3 \mathrm{ml} 0.1 \mathrm{M} \mathrm{NaOH}$ to adjust the $\mathrm{pH}$ (to 8.2-8.4). The agarose solution was poured into a Petri dish and gelled in a refrigerator $\left(5^{\circ} \mathrm{C}\right)$ for $8 \mathrm{~h}$ prior to cutting the gel into blocks of $0.5 \mathrm{~cm}^{2}$. These gels were then used for controls. For experimental treatments, 1, 10 or $100 \mu \mathrm{l}$ of the VOC bouquet (Table 2) were added to 3 beakers containing stillliquid agarose, after reaching room temperature, $8 \mathrm{~h}$ prior to starting the assays. Thus, tests were performed at 3 different concentrations of the diatom VOCs: 0.005, 0.05 and $0.5 \mu \mathrm{l} \mathrm{ml} \mathrm{l}^{-1}$ of agarose. The odour bouquet used in the agarose blocks (Table 2) was made from pure compounds and mimicked the molar ratios observed in activated Cocconeis scutellum parva. Only those compounds that were available and sufficiently pure (to avoid responses to any contaminating impurity) were included.

After cutting the $0.5 \mathrm{~cm}^{2}$ blocks (using a sterilised glass coverslip), glass capillary tubes of $14 \mathrm{~cm}$ length were prepared. The odour-containing block of agarose was added to one edge of the capillary glass and a block of control agarose was added to the other edge. This served to fix the position of the blocks in each Petri dish also in the 

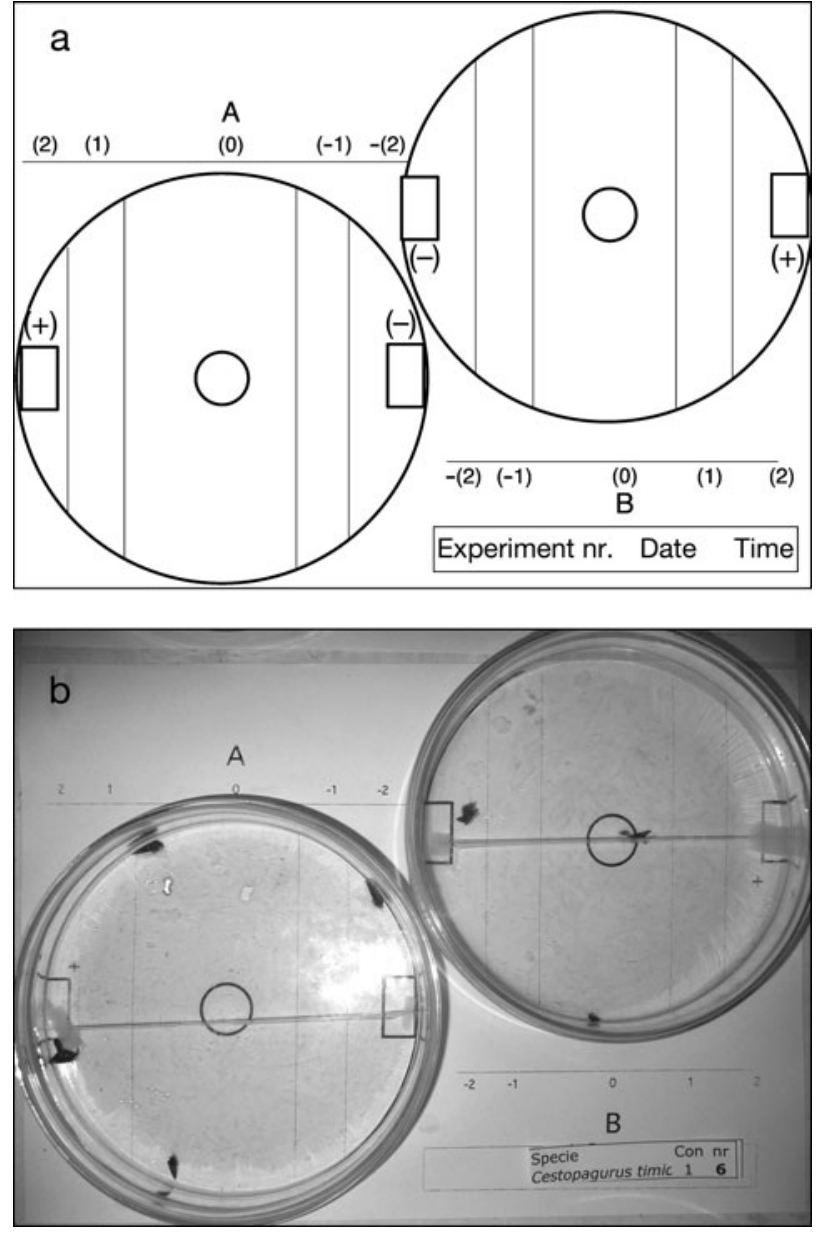

Fig. 1. (a) Experimental arenas on which Petri dishes were positioned. Volatile organic compound (VOC)-supplemented agarose was positioned in the (+) square, while the control agarose was positioned in the $(-)$ square. A and B indicate the 2 replicates for the same species present on each sheath. Three sheaths like this were used for each species, to obtain 6 replicates. (b) Petri dishes with agarose blocks and some invertebrates during an experimental trial

Table 2. Composition of the odour bouquet applied for the determination of its attractive and repellent activities for animals living in a Posidonia oceanica meadow. Final concentrations of the odour compounds in the agarose blocks, after addition of $1 \mu \mathrm{l}$ odour concentrate to $200 \mathrm{ml}$ of gel. The final concentrations of odour compounds were 10 and 100 times higher when 10 and $100 \mu \mathrm{l}$ were applied

\begin{tabular}{|lc|}
\hline Odour compound & Concentration $\left(\mu \mathrm{mol} \mathrm{l}^{-1}\right)$ \\
\hline Pentane-2,3-dione & 0.480 \\
Hexanal & 0.065 \\
$2(E), 4(E)$-Heptadienal & 0.041 \\
2(E)-Octenal & 0.170 \\
$2(E), 6(Z)-$ Nonadienal & 0.031 \\
$2(E), 4(E), 7(Z)$-Decatrienal & 0.075 \\
\hline
\end{tabular}

presence of large grazers. Finally, the capillary was positioned in the Petri dish, with the blocks in the appropriate positions according to the targets drawn and indicated as (+) (test sample) and (-) (control), as shown in Fig. 1b. The experiment was started when 5 individuals of each species (Table 1) were added to the central circle of each arena. The position of individuals of each species was recorded after $0,5,10,15$ and $20 \mathrm{~min}$, indicating the number of individuals present in each sector (namely the sectors $0,1,2,-1$ and -2).

Statistical analysis. The significance of differences in the distribution of individuals between the control areas $(-2,-1)$ and the VOC areas $(+2,+1)$ in the 6 trials for each species were tested by repeated-measures ANOVA with Prism 4 (Graphpad software). The mean number (with SD) of individuals present in each sector was calculated for each species at each time interval (from 0 to $20 \mathrm{~min}$ from the start of the experiment). An index representative of the attraction or repulsion towards the VOC-treated agarose was calculated for each species and each concentration according to the following equation:

$$
\text { Trend }=\mathrm{NR}_{2}+\mathrm{NR}_{1} / 2-\mathrm{NR}_{-2}-\mathrm{NR}_{-1} / 2
$$

where $\mathrm{NR}_{2}$ is the number of individuals in the sector $+2, N_{1}$ is the number of individuals in the sector +1 , $\mathrm{NR}_{-2}$ is the number of individuals in the sector -2 and $\mathrm{NR}_{-1}$ is the number of individuals in the sector -1 .

The 'Trend' scores calculated for each time lapse were then plotted along time, and a linear regression was calculated for each species for each concentration. The slope of each equation represents a synoptic value, indicating the tendency of each species to move towards the positive agarose block (positive value = attractive power), towards the control agarose block (negative value $=$ repellent power) or to remain in the centre, moving around without a clear preference (values close to $0=$ no effect).

However, the slope of each linear equation indicates the tendency to move towards a target, not the actual time spent in each sector. In fact, some invertebrates could slowly move towards the positive target, but they may remain most of the time in the negative sectors. Therefore, a second index was calculated as follows:

$$
\mathrm{INT}=\sum\left(\mathrm{T}_{1}+\mathrm{T}_{2}+\mathrm{T}_{3}+\mathrm{T}_{4}\right)
$$

where $T_{1}, T_{2}, T_{3}$ and $T_{4}$ are the 'Trend' values obtained in each of the 4 time lapses $(5,10,15$ and 20 min after the start). The INT index (integral time), therefore, indicates the total time spent by the experimental specimens in different sectors: positive values indicate a higher permanence in the positive sectors (1 or 2); negative values indicate a higher permanence in the negative sectors ( -1 or -2); and values close to 0 indicate scarce movements or equivalent movements in the 2 directions. 
The 2 scores obtained for each species, at each concentration, were then ordered in an $x-y$ plane, to obtain a comprehensive summary of the results. Ordering of a species in the first sector (positive 'INT', negative slope) indicates a preference for the VOC, but a tendency to move towards the control (see Fig. 3); ordering in the second sector (both positive values) indicates a high preference for the odours and a tendency to move towards the positive agarose block; ordering in the third sector (positive slope, negative INT) indicates that most individuals moved towards the odour sample, but remained most of the time in the negative sectors; and finally, ordering in the fourth sector indicates high repulsive tendency.

\section{RESULTS}

\section{Concentration of odour compounds in diatoms}

The diatom yield was 1640 cells $\mathrm{mm}^{-2}$ of the lawn on the bottom of the Petri dishes. Therefore, each Petri dish contained on average $2.5 \times 10^{7}$ diatoms. The analysis of all volatile odour compounds irrespective of the presence of given chemical functions was achieved by closed-loop stripping analysis. A typical chroma- togram is shown in Fig. 2. Mono-, di- and triunsaturated aldehydes with chain lengths from $\mathrm{C}_{5}$ to $\mathrm{C}_{10}$ were found in high numbers. Although several saturated aldehydes (heptanal, octanal, nonanal, decanal, undecanal) were also present as prominent peaks in the chromatograms, these compounds were, with the exception of hexanal, regarded as artefacts (Höckelmann \& Jüttner 2004). Fatty-acid cleavage products of $\mathrm{C}_{5}$ and $\mathrm{C}_{8}$ chain lengths were dominant and contained aldehydes, vinyl alcohols and diones as functional groups. Unexpected was the presence of $C_{9}(2(E), 6(Z)$-nonadienal) and $\mathrm{C}_{6}$ compounds represented by $3(Z)$-hexenal, 2(E)-hexenal, hexanal (that may have been contaminated by hexanal as an artefact) and hexanol-1. VOCs that were identified by comparison with authentic compounds are shown in Table 3. Monoterpenes and sulphur compounds were not observed in the odour bouquet of Cocconeis scutellum parva.

Femtogram amounts per cell were found for pentane-2,3-dione, hexanal, 3(Z)-hexenal, 2(E)-octenal, 3,5-octadien-2-one and $2(E), 4(Z), 7(Z)$-decatrienal. Since the cell volume of Cocconeis scutellum parva

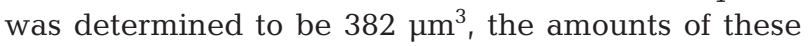
components produced per wounded cell were between 9.7 and $80 \mathrm{fg} \mathrm{cell}^{-1}$, corresponding to a concentration of 25 to $209 \mu \mathrm{mol} \mathrm{l^{-1 }}$ when no dilution is taken into

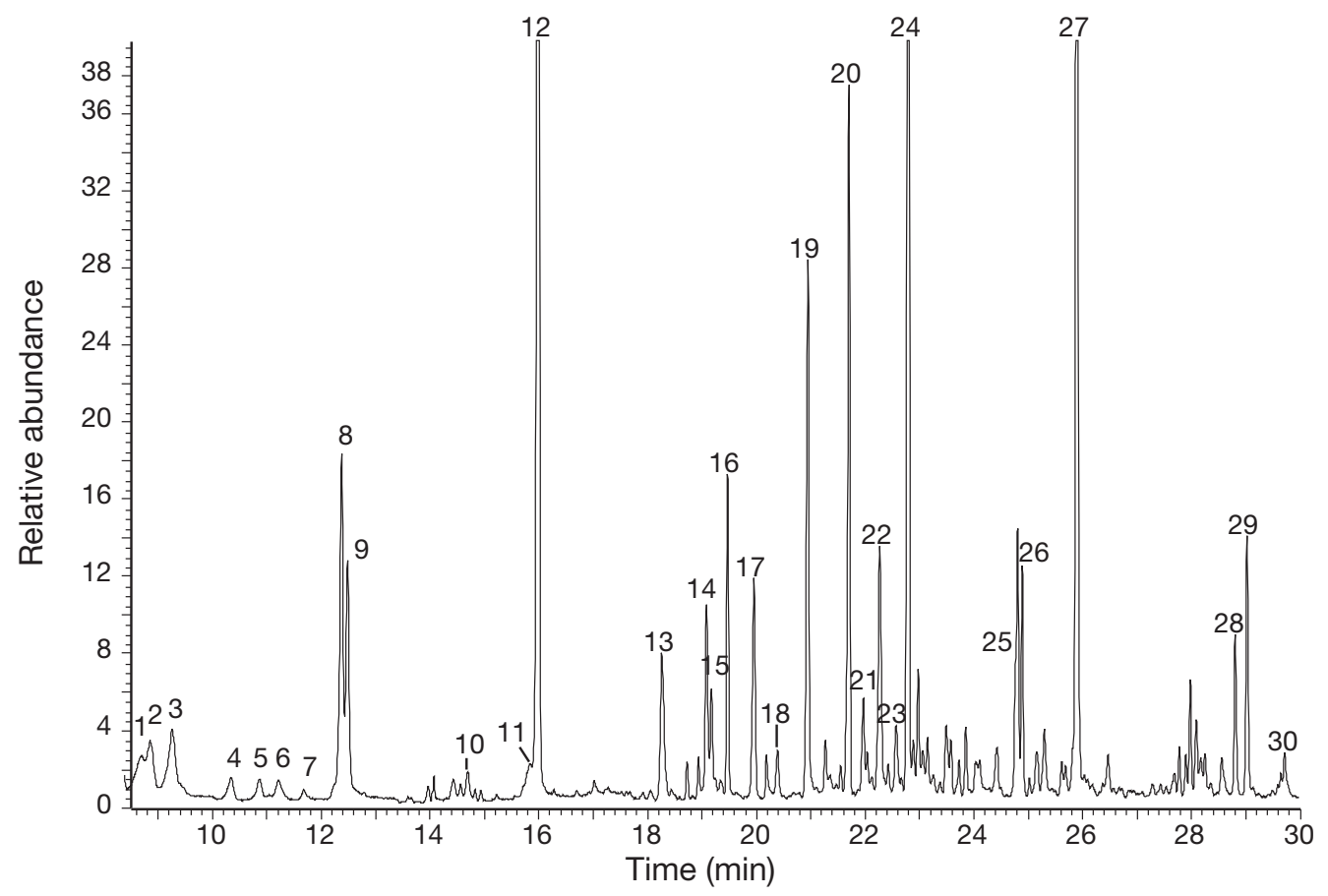

Fig. 2. GC-MS chromatogram of the volatile organic compounds (VOCs) released, after activation, by Cocconeis scutellum parva. Compounds that are artefacts or pollution products are in italics. 1: Pent-1-en-3-one, 2: pentanal, 3: pentane-2, 3-dione, 4: toluene, 5: 2(Z)-pentenal, 6: 2(E)-pentenal, 7: 1-hexen-3-one, 8: hexanal, 9: 3(Z)-hexenal, 10: (2E)-hexenal, 11: hexan-1-ol, 12: heptanal, 13: benzaldehyde and 2(E)-heptenal, 14: octane-3,4-dione, 15: oct-1-en-3-ol, 16: octanal, 17: 2( $E)$, 4(Z)-heptadienal, 18: 2(E), 4(E)-heptadienal, 19: 2-ethylhexanol, 20: 2(E)-octenal, 21: benzophenone, 22: 3,5-octadien-2-one, 23: 2,5-octadien-1-ol, 24: nonanal, 25: 2(E),6(Z)-nonadienal, 26: 2(E)-nonenal, 27: decanal, 28: undecanal, 29: 2(E),4(Z), 7(Z)-decatrienal, 30: 2(E), 4(E), 7(Z)-decatrienal 
Table 3. Volatile organic compounds (VOCs) of Cocconeis scutellum parva. Fragment ions or the ranges of fragment ions used for quantitative analyses $(\mathrm{m} / \mathrm{z})$, retention times $\left(\mathrm{R}_{\mathrm{t}}\right.$ on a DB $1301 \mathrm{GC}$ column, $30 \mathrm{~m}$ length, $0.32 \mathrm{~mm}$ inner diameter, $4 \mathrm{~min} 0^{\circ} \mathrm{C}$, then $5^{\circ} \mathrm{C} \mathrm{min}^{-1}$ up to $250^{\circ} \mathrm{C}$ ), and amounts of volatile compounds produced per cell are given for 2 independent determinations using $1(1 \mathrm{P})$ and 4 Petri dishes $(4 \mathrm{P})$. ag = attogram. Theor. conc. $=$ theoretical concentration of individual odour compounds after activation of the lipoxygenase cascade in the cell. nd = not determined

\begin{tabular}{|c|c|c|c|c|c|c|}
\hline \multirow[t]{2}{*}{ Compound } & \multirow[t]{2}{*}{$\mathrm{m} / \mathrm{z}$} & \multicolumn{2}{|c|}{$\mathrm{R}_{\mathrm{t}}(\min )$} & \multicolumn{2}{|c|}{ Cellular concentration (ag cell ${ }^{-1}$ ) } & \multirow{2}{*}{$\begin{array}{c}\text { Theor. conc } \\
\left(\mu \mathrm{mol} \mathrm{l}^{-1}\right)\end{array}$} \\
\hline & & $1 \mathrm{P}$ & $4 \mathrm{P}$ & $1 \mathrm{P}$ & $4 \mathrm{P}$ & \\
\hline 1-Penten-3-one & & 8.56 & 8.81 & nd & nd & nd \\
\hline Pentanal & & 8.74 & 8.98 & nd & nd & nd \\
\hline Pentane-2,3-dione & 43 & 9.16 & 9.37 & 6160 & 8000 & 209 \\
\hline 2(Z)-Pentenal & & 10.81 & 10.97 & nd & nd & nd \\
\hline 2(E)-Pentenal & & 11.16 & 11.32 & nd & nd & nd \\
\hline 1-Hexen-3-one & 33-99 & 11.63 & 11.78 & 76 & 78 & 2.1 \\
\hline Hexanal & 72 & 12.33 & 12.48 & 1560 & 1480 & 39 \\
\hline 3(Z)-Hexenal & $33-99$ & 12.59 & 12.59 & 1780 & 1560 & 42 \\
\hline 2(E)-Hexenal & 83 & 14.68 & 14.79 & 130 & 150 & 4.0 \\
\hline Hexanol-1 & 69 & 15.79 & 15.94 & 280 & 320 & 8.2 \\
\hline 2(E)-Heptenal & 70 & 18.29 & 18.38 & 120 & 84 & 2.0 \\
\hline Octane-2,3-dione & 99 & 19.07 & 19.16 & 400 & 480 & 8.8 \\
\hline 1-Octen-3-ol & 57 & 19.22 & 19.32 & 30 & 23 & 0.47 \\
\hline $2(E), 4(Z)$-Heptadienal & 81 & 19.94 & 20.03 & 560 & 740 & 18 \\
\hline $2(E), 4(E)$-Heptadienal & 81 & 20.37 & 20.46 & 170 & 170 & 4.1 \\
\hline 2(E)-Octenal & 70 & 21.67 & 21.77 & 2600 & 2090 & 43 \\
\hline 3,5-Octadien-2-one & $33-125$ & 22.25 & 22.33 & 820 & 1200 & 25 \\
\hline 2,5-Octadien-1-ol & $33-127$ & 22.57 & 22.63 & 130 & 90 & 1.9 \\
\hline 2(E),6(Z)-Nonadienal & 70 & 24.73 & 24.82 & 280 & 350 & 6.6 \\
\hline 2(E)-Nonenal & $33-141$ & 24.85 & 24.94 & 980 & 760 & 14 \\
\hline $2(E), 4(Z), 7(Z)$-Decatrienal & 79 & 28.97 & 29.05 & 1280 & 1520 & 26 \\
\hline $2(E), 4(E), 7(Z)$-Decatrienal & 79 & 29.66 & 29.75 & 390 & 340 & 5.9 \\
\hline
\end{tabular}

account (Table 3). These concentrations are the maximum that can be expected in a short time reaction period for C. scutellum parva that is attacked and disintegrated (see Jüttner 2005). These components are not present in live cells, but they represent the capacity of the cells for odour formation. The unstable $Z$-configuration was largely maintained during the isolation procedure and very little of the unsaturated aldehydes was isomerised to the E-configuration, indicating that the analytical method applied was very mild. The isomerisation was 6.8 to $8.8 \%$ for $3(Z)$-hexenal, 19 to $23 \%$ for 2(E), 4(Z)-heptadienal and 18 to $23 \%$ for $2(E), 4(E)$, $7(Z)$-decatrienal.

\section{Odour choice experiments}

Choice experiments indicated that some species of gastropod molluscs, such as Alvania lineata and Rissoa variabilis, are attracted by the Cocconeis scutellum parva VOCs even at the lowest concentration $(1 \mu \mathrm{l})$, while for other species, e.g. Gammarella fucicola, Hippolyte spp., Halacarus sp., Gibbula umbilicaris and Platynereis sp., this VOC concentration acts as a repellent (Fig. 3). Symphodus ocellatus, a benthic fish, demonstrated a clear attraction to the VOC at the lowest concentration, although its point was ordered in the

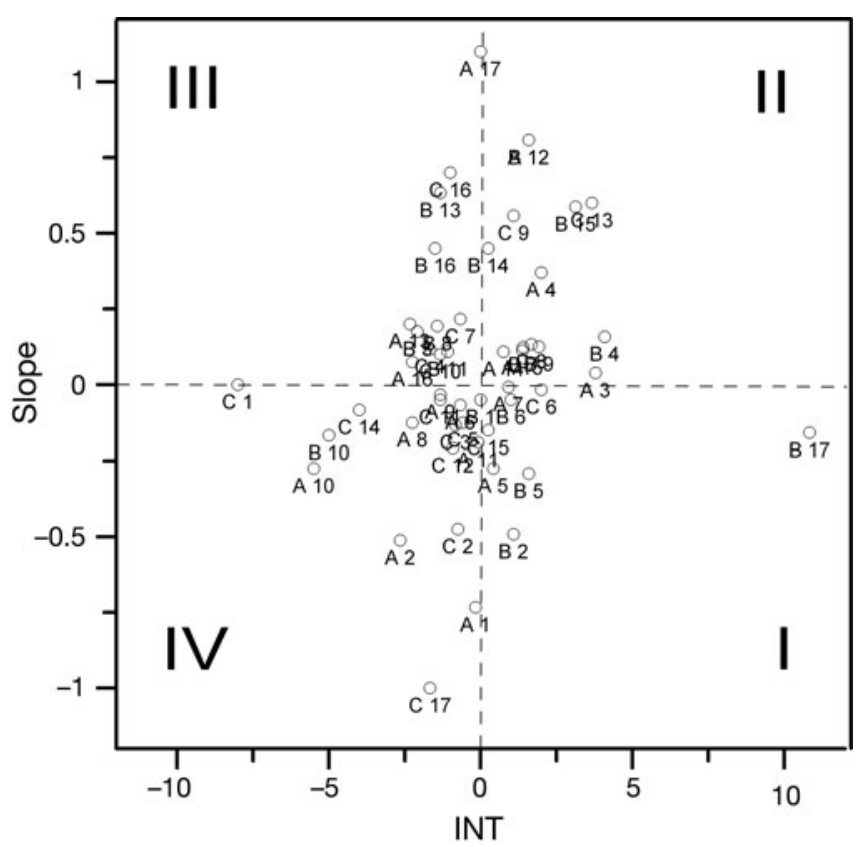

Fig. 3. Ordination into 1 of 4 sectors of species according to the scores reached for 'Slope' and 'INT' (integral time) (see 'Statistical analysis'). A, B and C indicate the 3 volatile organic compound (VOC) concentrations tested $(0.005,0.05$ and $0.5 \mu \mathrm{l}$ per $\mathrm{ml}$ of agarose gel, respectively). The numbers after these letters indicate the species considered, according to Table 1 
centre of the INT axis, probably due to the continuous movements of fish (faster than any invertebrate) in the experimental arena. These data are in partial agreement with those obtained using an intermediate concentration $(10 \mu \mathrm{l})$ of VOCs, suggesting that Symphodus ocellatus, Dynamene bifida, R. variabilis and Syllis prolifera are the species most attracted by the VOCs of Cocconeis scutellum parva. Gammarella fucicola, A. lineata, Platynereis sp., Gibbula umbilicaris and Halacarus sp. were strongly repelled by the odour compounds at this concentration. The situation differed slightly at the highest concentration $\left(0.5 \mu \mathrm{m} \mathrm{ml}^{-1}\right)$. Under these conditions, Halacarus sp., $R$. auriscalpium, Gibbula umbilicaris, Cestopagurus timidus and Syllis prolifera appear to have been attracted by the compound, while Hippolyte spp., Thoralus cranchii, $R$. variabilis and Symphodus ocellatus were repelled by the compound (Fig. 3). When we also consider, however, the slopes (tendency to move towards the VOC sample), Halacarus sp., Cestopagurus timidus, Pusillina sp. and Gibbula umbilicaris were the most attracted species, while Hippolyte spp., D. bifida, A. lineata and $R$. violacea were repelled by the highest concentration of the odour bouquet (Table 4). In addition, we clearly observed Symphodus ocellatus attracted to the VOC as food, at the lower concentrations. In fact, although they continuously moved in the Petri dishes, showing a schooling behaviour, when they approached the (+) agarose they also grazed its surface; this behaviour was never observed in the presence of the control (-) agarose.

Table 4. Summary of the main effects (attraction or repulsion) observed overall at the 3 different concentrations of volatile organic compounds (VOCs) tested. A,B,C $=0.005,0.05$ and $0.5 \mu \mathrm{l}$ per $\mathrm{ml}$ of agarose gel, respectively

\begin{tabular}{|c|c|c|c|}
\hline No. & Species & $\begin{array}{c}\text { Attracted at } \\
\text { concentration }\end{array}$ & $\begin{array}{c}\text { Repelled at } \\
\text { concentration }\end{array}$ \\
\hline 1 & Hippolyte varians & & $\mathrm{A}, \mathrm{B}, \mathrm{C}$ \\
\hline 2 & Hippolyte inermis & & $\mathrm{A}, \mathrm{B}, \mathrm{C}$ \\
\hline 3 & Alvania lineata & $\mathrm{A}$ & B \\
\hline 4 & Rissoa variabilis & $\mathrm{A}, \mathrm{B}$ & $\mathrm{C}$ \\
\hline 5 & R. violacea & & $\mathrm{C}$ \\
\hline 6 & $R$. auriscalpium & $\mathrm{C}$ & $\mathrm{A}$ \\
\hline 7 & Pusillina sp. & $\mathrm{B}$ & \\
\hline 8 & Gibbula umbilicaris & $\mathrm{C}$ & $\mathrm{A}, \mathrm{B}$ \\
\hline 9 & Cestopagurus timidus & $\mathrm{B}, \mathrm{C}$ & \\
\hline 10 & Gammarella fucicola & & $\mathrm{A}, \mathrm{B}$ \\
\hline 11 & Bittium reticulatum & & $\mathrm{A}, \mathrm{C}$ \\
\hline 12 & Dynamene cf. bifida & $\mathrm{A}, \mathrm{B}$ & $\mathrm{C}$ \\
\hline 13 & Halacarus sp. & $\mathrm{C}$ & $\mathrm{A}, \mathrm{B}$ \\
\hline 14 & Thoralus cranchii & $\mathrm{A}, \mathrm{B}$ & $\mathrm{C}$ \\
\hline 15 & Syllis prolifera & $\mathrm{A}, \mathrm{B}, \mathrm{C}$ & \\
\hline 16 & Platynereis sp. & & $\mathrm{A}, \mathrm{B}$ \\
\hline 17 & Symphodus ocellatus & $\mathrm{A}, \mathrm{B}$ & $\mathrm{C}$ \\
\hline
\end{tabular}

\section{DISCUSSION}

A feature of several planktonic and benthic, freshwater and marine diatoms is their ability to produce large amounts of volatile, highly odoriferous, lipoxygenase-mediated unsaturated fatty-acid degradation products. Two major groups of diatoms can be distinguished. One group produces polyunsaturated cyclic and non-cyclic hydrocarbons in an oxygen-dependent reaction, but it does not produce volatile components with oxygen-containing functional groups (Wendel \& Jüttner 1996). The other group of diatoms produces volatiles that are primarily represented by unsaturated aldehydes with $\mathrm{C}$-chain lengths of $\mathrm{C}_{7}$ (heptadienals), $\mathrm{C}_{8}$ (octadienals and octatrienals) and $\mathrm{C}_{10}$ (decadienals and decatrienals). Unsaturated hydrocarbons are missing in this group (Wendel \& Jüttner 1996, Wichard et al. 2005). A new chemotype is represented by Cocconeis scutellum parva. This diatom produces unsaturated aldehydes with chain lengths in the range between $\mathrm{C}_{5}$ and $\mathrm{C}_{10}$ in high amounts, but no unsaturated hydrocarbons. Many of these compounds are described here for the first time in diatoms. A new group is represented by diketones such as pentane2,4-dione and octane-2,3-dione. Octane-2,3-dione, which has a pleasant odour, has been observed during mastication of grass (Young et al. 1997) and it can be expected to be a lipoxygenase-mediated compound as well. In addition, we observed the occurrence of monounsaturated aldehydes, among which 2(E)octenal was released in remarkable amounts.

The presence of $\mathrm{C}_{6}$ compounds was unexpected. They are typical components of lipoxygenases of higher plants. These compounds have not yet been described for diatoms or any algal metabolism. Unlike in higher plants (Croft et al. 1993), the unsaturated $\mathrm{C}_{6}$ aldehydes of Cocconeis scutellum parva were not reduced to the corresponding alcohols and not esterified with acetate. It is hypothesised that these compounds may mimic the presence of a higher plant (in our case, Posidonia oceanica, which also exhibits the higher plant lipoxygenase pathway; data not shown). High lipoxygenase activities have frequently been found for biofilm-forming diatoms (Jüttner \& Dürst 1997, Jüttner 2005, Fink et al. 2006), but $\mathrm{C}_{6}$ components seem to be unique for this epiphytic species.

The amount of polyunsaturated aldehydes per cell found in the present study was in the lower range reported for diatoms (Wichard et al. 2005, Ribalet et al. 2007). However, methodological differences may influence the results and seriously affect the observed amounts of aldehydes. Wichard et al. (2005) activated the lipoxygenase cascades in diatoms by application of the cytotoxic compound O- $(2,3,4,5,6$-pentafluorobenzyl)-hydroxylamine hydrochloride. Concomitantly this 
reagent efficiently traps the formed aldehydes and protects them from being subject to further reactions and losses caused by their volatility. The molar concentrations of the odour compounds (representing the maximum we may expect in a freshly disintegrated cell suspension of Cocconeis scutellum parva) are still high enough to be detected as cues by invertebrate and fish odour receptors. Odour receptors are active in the nanomolar range (Boland et al. 1995) and they allow for an appreciable dilution of the odour bouquet before the detection limit is reached.

The results of the choice experiments confirmed that odour compounds produced by Cocconeis scutellum parva are recognised by most invertebrates and trigger different, often unpredicted reactions in individual species. The fish Symphodus ocellatus and such invertebrates as Dynamene bifida, Syllis prolifera, Rissoa variabilis and Cestopagurus timidus were attracted by the compounds applied at the intermediate concentration. The latter species are herbivores, and the attraction observed, therefore, is according to our expectations. The reaction observed at the highest concentration was not always in accordance with our expectations, since 'sensitive' species could be confused in an environment that is over-saturated by the intense odour of these diatoms (Pohnert 2004). In fact, species such as Symphodus ocellatus and Thoralus cranchii that were attracted by the compound at low and intermediate concentrations, were repelled at the highest concentration. However, Halacarus sp., $R$. auriscalpium, Gibbula umbilicaris, Cestopagurus timidus and Syllis prolifera were attracted by the compound at the highest concentration, and they are all hosted in the leaf stratum of Posidonia oceanica, and considered typical grazers of the epiphytic layer. Therefore, we can argue that some grazers are particularly accustomed to the odour of chewed diatoms (Fink et al. 2006) and probably attracted by other animals grazing in the same area, following an odour patch. A similar behaviour was observed in the mangrove snail Terebralia palustris by Fratini et al. (2001): active feeding of snails on the leaf litter led to the release of odour compounds and subsequently to the attraction of conspecifics.

Interestingly, Hippolyte inermis and $H$. varians, both typical hosts of the leaf stratum of Posidonia oceanica and grazers of leaf epiphytes (including Cocconeis spp. diatoms; Zupo 2001), appear to be repelled by the VOCs. Therefore, repulsion to the odour of the diatoms could appear to contradict previous observations (Zupo 1994). However, the VOCs in this study considered are released in the environment after the wounding of the diatom cytoplasmic membrane (Pohnert 2002, D'Ippolito et al. 2004). Since hippolytid shrimps are subjected to high predation pressure and their behaviour is influ- enced by the need to avoid predation (Zupo 1994, Bedini et al. 1997, Zupo \& Nelson 1997), the diffusion of wound-activated VOCs may indicate the presence of predators chewing parts of $P$. oceanica and its epiphytes.

In contrast, the odour attracts other grazers, e.g. some gastropod molluscs. In fact, gastropods continuously search for exploitable epiphytes and the odour of wounded diatoms indicates abundance of possible food. Molluscs are also very sensitive to the presence of the VOCs and some gastropods positively react to low and intermediate concentrations. Repellence was exhibited by Gibbula umbilicaris, but only at the lowest concentrations, while at increasing concentrations this gastropod appeared attracted by the 'odour' of diatoms. In this case, the observed behaviour was exactly opposite of that shown by other molluscs (e.g. Rissoa spp.). The different localisation of the 2 gastropods along the leaves of Posidonia oceanica may explain the opposing reactions observed. In fact, Rissoa spp. live in the middle part of the leaf, which is generally covered by diatoms, while $G$. umbilicaris lives in the top part of the leaf, which is heavily epiphytised by filamentous and encrusting macrophytes (Mazzella et al. 1991).

Therefore the same signal, i.e. the odour of smashed diatoms, may represent an attractant for some invertebrates that need to maximise the search for food, and a repellent for other invertebrates (Fink 2007), for which mimicry and defence from predators represent the most important behavioural constraints (Lamberti et al. 1995). This is not surprising, since the same compound produced by benthic diatoms, e.g. 2(E),4(E)-octadienal, attracts the mollusc Radix ovata (Fink et al. 2006), but serves as a repellent for crustaceans at high concentrations (Jüttner 2005).

Some of the compounds produced by diatoms when wounded are defence compounds, such as highly unsaturated fatty acids. For example, 5, 8,11,14,17-eicosapentaenoic acid has been shown to be toxic for freshwater herbivores (Jüttner 2001) and we know that this compound is largely present in Cocconeis scutellum parva (Nappo et al. 2009). However, since Hippolyte inermis normally feeds on these diatoms (Zupo 2000, 2001), it is evident that the same 'defence' compounds may have variable effects on individual invertebrate species. Similar substances were also found in freshwater environments (Jüttner \& Wurster 1984), and it was demonstrated that diatoms produced these compounds (Wendel \& Jüttner 1996, Jüttner \& Dürst 1997). In conclusion, as a paradox, VOCs produced by $C$. scutellum parva induce an escape reaction in $H$. inermis, which actively feed on them, but they attract several other grazers, thereby playing the role of foraging kairomones, indicating the presence of abundant food and the possibility to join a grazer's banquet. The 
mosaic of results obtained at various concentrations, in different species, indicates that these wound-activated infochemicals are well-recognised by most invertebrates living in seagrass meadows (Kessler \& Baldwin 2001) and they play a variable but important role, producing complex patterns of behavioural reactions and a web of chemical communications (Croll 1983, Watson \& Ridal 2004) among diatoms and the invertebrates associated with the leaf stratum of Posidonia oceanica.

Acknowledgements. We thank Dr. J. Schmid (Givaudan Schweiz AG, Dübendorf, Switzerland) for the sample of octane-2,3-dione. We thank Dr. M. Williams, Dr. K. Kroeker and R. Messina for their thorough reading of the English manuscript. We thank M. C. Gambi for the taxonomical identification of polychaetes, M. B. Scipione for the identification of amphipods, M. Lorenti for the identification of isopods, F. Patti and F. Criscione for the identification of molluscs and D. Sarno for calculating the diatom volume. L. Pizzo (degree thesis at the Functional and Evolutionary Ecology laboratory) assisted in the conduction of choice experiments. This research was partially conducted under the European Community-funded Research Program Pharmapox (E.U. 004800).

\section{LITERATURE CITED}

Bedini R, Canali MG, Baldi C (1997) Mimetismo criptico nei crostacei della prateria a Posidonia oceanica (L.) Delile. Biol Mar Mediterr 4:353-355

Boland W, Pohnert G, Maier I (1995) Pericyclic reactions in nature: spontaneous Cope rearrangement inactivates algae pheromones. Angew Chem Int Ed Engl 34:1602-1604

Buia MC, Zupo V, Mazzella L (1992) Primary production and growth dynamics in Posidonia oceanica. PSZN I: Mar Ecol 13:2-16

Buia MC, Gambi MC, Zupo V (2000) Structure and functioning of Mediterranean seagrass ecosystems: an overview. Biol Mar Mediterr 7:167-190

Carotenuto Y, Wichard T, Pohnert G, Lampert W (2005) Lifehistory responses of Daphnia pulicaria to diets containing freshwater diatoms: effects of nutritional quality versus polyunsaturated aldehydes. Limnol Oceanogr 50:449-454

Chepurnov VA, Mann DG, Sabbe K, Vyverman W (2004) Experimental studies on sexual reproduction in diatoms. Int Rev Cytol 237:91-99

Croft KPC, Jüttner F, Slusarenko AJ (1993) Volatile products of the lipoxygenase pathway evolved from Phaseolus vulgaris (L.) leaves inoculated with Pseudomonas syringae pv phaseolicola. Plant Physiol 101:13-24

Croll RP (1983) Gastropod chemoreception. Biol Rev Camb Philos Soc 58:293-319

D'Ippolito G, Tucci S, Cutignano A, Romano G, Cimino G, Miralto A, Fontana A (2004) The role of complex lipids in the synthesis of bioactive aldehydes of the marine diatom Skeletonema costatum. Biochim Biophys Acta 1686: 100-107

De Stefano M, Marino D, Mazzella L (2000) Marine taxa of Cocconeis on leaves of Posidonia oceanica, including a new species and two new varieties. Eur J Phycol 35:225-242

> Durrer M, Zimmermann U, Jüttner F (1999) Dissolved and particle-bound geosmin in a mesotrophic lake (Lake Zürich): spatial and seasonal distribution and the effect of grazers. Water Res 33:3628-3636
Evans EW (1982) Feeding specialization in predatory insects hunting and attack behavior of 2 stinkbug species (Hemiptera - Pentatomidae). Am Midl Nat 108:96-104

> Fink P (2007) Ecological functions of volatile organic compounds in aquatic systems. Mar Freshw Behav Physiol 40: $155-168$

Fink P, von Elert E, Jüttner F (2006) Oxylipins from freshwater diatoms act as attractants for a benthic herbivore. Arch Hydrobiol 167:561-574

Fratini S, Cannicci S, Vannini M (2001) Feeding clusters and olfaction in the mangrove snail Terebralia palustris (Linnaeus) (Potamididae: Gastropoda). J Exp Mar Biol Ecol 261:173-183

Hillebrand H, Durselen CD, Kirschtel D, Pollingher U, Zohary $\mathrm{T}$ (1999) Biovolume calculation for pelagic and benthic microalgae. J Phycol 35:403-424

Höckelmann C, Jüttner F (2004) Volatile organic compounds (VOC) analysis and sources of limonene, cyclohexanone and straight chain aldehydes in axenic cultures of Calothrix and Plectonema. Water Sci Technol 49:47-54

Jüttner F (2001) Liberation of 5, 8,11,14,17-eicosapentaenoic acid and other polyunsaturated fatty acids from lipids as a grazer defense reaction in epilithic diatom biofilms. J Phycol 37:744-755

> Jüttner F (2005) Evidence that polyunsaturated aldehydes of diatoms are repellents for pelagic crustacean grazers. Aquat Ecol 39:271-282

Jüttner F, Dürst U (1997) High lipoxygenase activities in epilithic biofilms of diatoms. Arch Hydrobiol 138:451-463

Jüttner F, Wurster K (1984) Evidence of ectocarpene and dictyopterenes $\mathrm{A}$ and $\mathrm{C}^{\prime}$ in the water of a freshwater lake. Limnol Oceanogr 29:1322-1324

Kessler A, Baldwin IT (2001) Defensive function of herbivoreinduced plant volatile emissions in nature. Science 291: 2141-2144

> Lamberti GA, Gregory SV, Ashkenas LR, Li JL, Steinman AD, McIntire CD (1995) Influence of grazer type and abundance on plant-herbivore interactions in streams. Hydrobiologia 306:179-188

Mazzella L, Buia MC (1989) Variazioni a lungo termine in alcuni parametri strutturali di una prateria a Posidonia oceanica. Nova Thalassia 10:533-542

Mazzella L, Buia MC, Gambi MC, Lorenti M, Russo GF, Scipione MB, Zupo V (1991) Plant-animal trophic relationships in the Posidonia oceanica ecosystem of the Mediterranean Sea: a review. In: Keegan JF (ed) Plant-animal interactions in marine benthos. Clarendon Press, Oxford, p 165-188

> Michael TS, Shin HW, Hanna R, Spafford DC (2008) A review of epiphyte community development: surface interactions and settlement on seagrass. J Environ Biol 29:629-638

Miralto A, Barone G, Romano G, Poulet SA and others (1999) The insidious effect of diatoms on copepod reproduction. Nature 402:173-176

Nappo M, Berkov S, Codina C, Avila C, Messina P, Zupo V, Bastida J (2009) Metabolite profiling of the benthic diatom Cocconeis scutellum by GC-MS. J Appl Phycol 21:295-306

> Orth RJ, Carruthers TJB, Dennison WC, Duarte CM and others (2006) A global crisis for seagrass ecosystems. Bioscience 56:987-996

Pohnert G (2000) Wound-activated chemical defense in unicellular planktonic algae. Angew Chem Int Ed 39:4352-4355

Pohnert G (2002) Phospholipase A2 activity triggers the wound-activated chemical defense in the diatom Thalassiosira rotula. Plant Physiol 129:103-111

Pohnert G (2004) Chemical defense strategies of marine organisms. Chemistry of pheromones and other semiochemicals. Top Curr Chem 239:179-219 
Ribalet F, Wichard T, Pohnert G, Ianora A, Miralto A, Casotti R (2007) Age and nutrient limitation enhance polyunsaturated aldehydes production in marine diatoms. Phytochemistry 68:2059-2067

Ruther J, Meiners T, Steidle JLM (2002) Rich in phenomena lacking in terms. A classification of kairomones. Chemoecol 12:161-167

Sun J, Liu D (2003) Geometric models for calculating cell biovolume and surface area for phytoplankton. J Plankton Res 25:1331-1346

Terlizzi A, Conte E, Zupo V, Mazzella L (2000) Biofouling succession on silicone fouling-release surfaces: long term exposure tests in the harbour of Ischia, Italy. Biofouling 15: 327-342

Tressl R, Bahri D, Engel KH (1982) Formation of eight-carbon and ten-carbon components in mushrooms (Agaricus campestris). J Agric Food Chem 30:89-93

Watson SB, Ridal J (2004) Periphyton: a primary source of widespread and severe taste and odour. Water Sci Technol 49:33-39

Wendel T, Jüttner F (1996) Lipoxygenase-mediated formation of hydrocarbons and unsaturated aldehydes in freshwater diatoms. Phytochemistry 41:1445-1449

Wichard T, Poulet SA, Halsband-Lenk C, Albaina A, Harris R, Liu D, Pohnert G (2005) Survey of the chemical defence potential of diatoms: screening of fifty one species for $\alpha, \beta, \gamma, \delta$-unsaturated aldehydes. J Chem Ecol 31:949-958

Editorial responsibility: James McClintock, Birmingham, Alabama, USA
Wiesemeier T, Hay M, Pohnert G (2007) The potential role of wound-activated volatile release in the chemical defence of the brown alga Dictyota dichotoma: blend recognition by marine herbivores. Aquat Sci 69:403-412

Young OA, Berdagué JL, Viallon C, Rousset-Akrim S, Theriez M (1997) Fat-borne volatiles and sheepmeat odour. Meat Sci 45:183-200

Zupo V (1994) Strategies of sexual inversion in Hippolyte inermis Leach (Crustacea, Decapoda) from a Mediterranean seagrass meadow. J Exp Mar Biol Ecol 178: $131-145$

Zupo V (2000) Effect of microalgal food on the sex reversal of Hippolyte inermis (Crustacea: Decapoda). Mar Ecol Prog Ser 201:251-259

Zupo V (2001) Influence of diet on the sex differentiation of Hippolyte inermis Leach (Decapoda: Natantia) in the field. Hydrobiologia 449:131-140

Zupo V, Messina P (2007) How do dietary diatoms cause the sex reversal of the shrimp Hippolyte inermis Leach (Crustacea, Decapoda). Mar Biol 151:907-917

Zupo V, Nelson WG (1997) Influence of light on the spatial distribution and the ecology of Hippolyte zostericola (Smith) (Decapoda: Natantia) in the Indian River Lagoon (Florida, USA). Biol Mar Mediterr 4:156-166

Zupo V, Messina P, Buttino I, Sagi A and others (2007) Do benthic and planktonic diatoms produce equivalent effects in crustaceans? Mar Freshw Behav Physiol 40:1-13

Submitted: February 11, 2009; Accepted: July 3, 2009

Proofs received from author(s): January 26, 2010 